\title{
PENGEMBANGAN MODEL REGRESI POLINOMIAL BERGANDA PADA KASUS DATA PEMASARAN
}

\author{
Julyanti S. Malensang ${ }^{1)}$, Hanny Komalig ${ }^{1)}$, Djoni Hatidja ${ }^{1)}$ \\ ${ }^{1)}$ Program Studi Matematika FMIPA Universitas Sam Ratulangi, Manado 95115 \\ e-mail: July_easter10@yahoo.com, hanny07@yahoo.com, dhatidja@yahoo.com
}

\begin{abstract}
ABSTRAK
Regresi polinomial merupakan regresi linier berganda yang dibentuk dengan menjumlahkan pengaruh variabel prediktor $(X)$ yang dipangkatkan secara meningkat sampai orde ke- $k$. Model regresi polinomial, struktur analisisnya sama dengan model regresi linier berganda. Artinya, setiap pangkat atau orde variabel prediktor $(X)$ pada model polinomial, merupakan transformasi variabel awal dan dipandang sebagai sebuah variabel prediktor $(X)$ baru dalam linier berganda. Model terbaik dari kelima model yang telah diuji adalah persamaan regresi model ke-5. Hal ini dapat dilihat dari nilai koefisien determinasi sebesar $99,1 \%$ dan nilai $R-S q(a d j)=98,8 \%$, karena nilai $R^{2}$ mendekati nilai yang telah diatur dan berdasarkan pengujian yang dilakukan ternyata seluruh koefisien-koefisien dari setiap variabel bebas signifikan serta ada kelengkungan yang bersifat kubik (pangkat 3) terhadap data $X_{3}$ terhadap $Y$.
\end{abstract}

Kata kunci: Pemasaran, Regresi polynomial.

\section{DEVELOPMENT OF MULTIPOLYNOMIAL REGRESSION MODEL ON MARKETING DATA CASE}

\begin{abstract}
Polynomial regression is linear regression multiple were created by summing the effect of each predictor variable $(X)$ is raised to increase to the order of the $k$. Polynomial regression model, has the same structure with linear regression models. That is, any rank or order predictor variable $(X)$ in polynomial models, an initial variable transformation and is seen as a predictor variable $(X)$ has the linear regression. The best model of the six models tested were equation regression model to5. It can be seen from the value of the coefficient of determination of $99.1 \%$ and a value of $R-S q$ $($ adj $)=98.8 \%$, due to the value of $R^{2}$ close to the value that has been set up and based on tests performed turns all the coefficients of each independent variable significantly and there are cubic curvature (rank 3) to the data $X_{3}$ to $Y$.
\end{abstract}

Keywords : Marketing, Polynomial regression.

\section{PENDAHULUAN}

Analisis regresi merupakan salah satu alat dalam pengambilan keputusan yang banyak digunakan dalam pembangunan model matematis, karena model regresi dapat digunakan untuk mengukur kekuatan hubungan antara variabel respons dan variabel prediktor, mengetahui pengaruh suatu atau beberapa variabel prediktor terhadap variabel respons, dan berguna untuk memprediksi pengaruh suatu variabel atau beberapa variable respons (Iriawan dan Astuti, 2006).
Dalam penelitian ini, metode regresi polinomial berganda diterapkan pada model regresi linier berganda, dimana regresi polinomial bersifat fleksibel dan berguna di mana model dapat dikembangkan secara empiris dan cocok untuk menentukan adanya kelengkungan polinomial dalam data.

Tujuan penelitian ini adalah mengaplikasikan model regresi polinomial berganda pada kasus data pemasaran dan menentukan derajat polinomial dari variabel bebas dalam struktur data tersebut. 


\section{TINJAUAN PUSTAKA}

\section{Pemasaran}

Dalam kegiatan pemasaran ada banyak istilah yang dapat digunakan. Antara lain adalah penjualan, rekening aktif, merek dan biaya. Penjualan adalah suatu usaha yang dilakukan untuk memasarkan barang atau jasa dalam suatu badan atau perusahaan atau distributor kepada konsumen yang memiliki kepentingan atas barang atau jasa tersebut. Biaya adalah kas atau nilai setara kas yang dikorbankan untuk barang atau jasa yang diharapkan memberi manfaat pada saat ini atau di masa mendatang bagi organisasi (Henry Simamora, 2002). Rekening aktif merupakan rekening bank yang sering kali bermutasi berupa penyetoran atau penarikan. Merek dagang adalah nama atau simbol yang diasosiasikan dengan produk/jasa dan menimbulkan arti psikologis/asosiasi. Secara konvensional, merek dapat berupa nama, kata, frasa, logo, lambang, desain, gambar, atau kombinasi dua atau lebih unsur tersebut.

\section{Analisis regresi}

Analisis regresi adalah suatu analisis yang bertujuan untuk menunjukkan hubungan matematis antara variabel terikat dengan variabel bebas. Tujuan utama dalam penggunaan analisis ini adalah untuk meramalkan nilai dari suatu variabel dalam hubungannya dengan variabel lainnya yang dapat diketahui melalui persamaan regresi.

\section{Analisis regresis berganda}

Apabila dalam persamaan regresi linier mencakup lebih dari dua prediktor atau variabel bebas maka regresi tersebut dinamakan regresi linier berganda (multiple linear regression). Model Regresi linier berganda memiliki persamaan regresi secara umum berbentuk seperti berikut:

$$
Y=\beta_{0}+\beta_{1} X_{1}+\beta_{2} X_{2}+\beta_{3} X_{3}+\ldots+\beta_{k} X_{k}+\varepsilon
$$

dimana $Y$ adalah variabel terikat/bergantung, $X_{1}, X_{2}, X_{3}, \ldots, X_{k}$ adalah variabel-variabel bebas, $\beta_{0}$ adalah intersep, dan $\beta_{1}, \beta_{2}, \beta_{3}, \ldots$, $\beta_{k}$ adalah parameter koefisien-koefisien regresi

Asumsi-asumsi model regresi klasik yang harus dipenuhi dalam analisis regresi linier berganda adalah :
1. Model regresi bersifat linier

2. $X$ diasumsikan nonstokastik

3. Nilai rata-rata kesalahan adalah nol atau $E\left(\varepsilon_{i}\right)=0$

4. Homoskedastisitas, artinya varian kesalahan sama untuk setiap periode dinyatakan dalam bentuk matematis, $\operatorname{Var}\left(\varepsilon_{i} \mid X_{i}\right)=\sigma^{2}$

5. Tidak ada autokorelasi antar kesalahan (antara $\varepsilon_{i}$ dan $\varepsilon_{j}$ tidak ada korelasinya),

6. Antara $\varepsilon$ dan $X$ saling bebas, sehingga covarians $(\varepsilon X)=0$

7. Tidak ada multikolinieritas yang sempurna antar variabel bebas.

8. Jumlah observasi $n$ harus lebih besar daripada jumlah parameter yang diestimasi (jumlah variabel bebas).

9. Adanya variabilitas dalam nilai $X$, artinya nilai $X$ harus berbeda.

10. Model regresi telah dispesifikasikan secara benar dengan kata lain tidak ada bias (kesalahan) spesifikasi dalam model yang digunakan dalam analisis empiris.

\section{Regresi Polinomial Berganda}

Regresi polinomial merupakan model regresi linier yang dibentuk dengan menjumlahkan pengaruh masing-masing variabel prediktor $(X)$ yang dipangkatkan meningkat sampai orde ke-k. Secara umum, model regresi polinomial ditulis dalam bentuk :

$$
Y=b_{0}+b_{1} X+b_{2} X^{2}+\ldots+b_{k} X^{k}+\varepsilon
$$

Dimana :

$Y=$ variabel respons

$b_{0}=$ intersep

$b_{1}, b_{2}, \ldots, b_{k}=$ koefisien-koefisien regresi

$X=$ variabel prediktor

$\varepsilon=$ faktor pengganggu yang tidak dapat dijelaskan oleh model regresi.

Model diatas menunjukkan bentuk modifikasi dari model regresi linier berganda, dimana $X_{1}=X, \quad X_{2}=X^{2}, \ldots, \quad X_{k}=X^{k}$ sehingga dapat ditulis menjadi bentuk :

$$
Y=b_{0}+b_{1} X_{1}+b_{2} X_{2}+b_{3} X_{3}+\ldots+b_{k} X_{k}+\varepsilon
$$




\section{METODOLOGI PENELITIAN}

\section{Metode Analisis Data}

Data dianalisis dengan menggunakan analisis regresi berganda dengan tujuan untuk mengetahui pengaruh variabel-variabel bebas terhadap variabel terikat secara serentak dan menguji koefisien-koefisien regresi tersebut secara individu.

Data yang digunakan dalam penelitian ini adalah data dari suatu kepustakaan atau kajian pustaka. Kemudian dilakukan analisis regresi berganda dengan tujuan untuk mengetahui pengaruh variabel-variabel bebas terhadap variabel terikat secara serentak dan menguji koefisien-koefisien regresi tersebut secara individu.

Analisis data dilakukan dengan menggunakan analisis regresi dengan bantuan software Minitab. Dengan langkah-langkah yang dilakukan dalam analisis regresi adalah sebagai berikut :

1. Menentukan prediksi model regresi dan koefisien regresi untuk model-model berikut : Model 1:

$Y=b_{01}+b_{11} X_{1}+b_{21} X_{2}+b_{31} X_{3}$

Model 2 :

$Y=b_{02}+b_{12} X_{2}+b_{22} X_{3}$

Model 3 :

$Y=b_{03}+b_{13} X_{2}+b_{23} X_{2}^{2}+b_{33} X_{2}^{3}+b_{43} X_{3}+b_{53} X_{3}^{2}+b_{63} X_{3}^{3}$

Model 4 :

$Y=b_{04}+b_{14} X_{3}+b_{24} X_{3}^{2}+b_{34} X_{3}^{3}$

Model 5 :

$Y=b_{05}+b_{15} X_{2}+b_{25} X_{3}+b_{35} X_{3}^{2}+b_{45} X_{3}^{3}$

Menentukan koefisien determinasi $\left(R^{2}\right)$ dan koefisien determinasi yang telah disesuaikan, Adjusted $R$ Square $\left(R^{2} a d j\right)$ untuk melihat pengaruh baik/buruknya kecocokan model dengan data.

2. Membuat tabel Anova

3. Uji parameter model regresi

- Uji-F dilakukan untuk mengetahui apakah variabel-variabel bebas secara bersamaan berpengaruh terhadap variabel terikat dengan menguji koefisien-koefisien regresi.

- Uji- $t$ dilakukan untuk melihat pengaruh variabel-variabel bebas terhadap variabel terikat dengan menguji koefisien-koefisien regresi secara parsial.

4. Pembahasan dan pengambilan kesimpulan.

\section{HASIL DAN PEMBAHASAN}

Untuk pemeriksaan model mana yang baik digunakan pada analisis regresi, dapat ditunjukkan dengan perbandingan nilai $R^{2}$ dan nilai $R-S q$ (adj) pada keseluruhan model persamaan pada Tabel 1.

Tabel 1: Perbandingan Model

\begin{tabular}{|l|c|c|c|}
\hline $\begin{array}{c}\text { Model } \\
\text { Regresi } \\
\text { Polinomial }\end{array}$ & $\begin{array}{c}\text { Nilai-nilai } \\
\text { dari } \boldsymbol{R}^{2} \text { dan } \\
\boldsymbol{R}^{2} \boldsymbol{a d j}\end{array}$ & Variabel & $\begin{array}{c}\boldsymbol{p} \text { - } \\
\text { value }\end{array}$ \\
\hline Model 1 & $65.6 \%$, & $X_{1}$ & 0.516 \\
& $56.2 \%$ & $X_{2}$ & 0.004 \\
& & $X_{3}$ & 0.046 \\
\hline Model 2 & $64.2 \%$, & $X_{2}$ & 0.003 \\
& $58.2 \%$ & $X_{3}$ & 0.043 \\
\hline Model 3 & $99.2 \%$, & $X_{2}$ & 0.828 \\
& $98.5 \%$ & $X_{2}^{2}$ & 0.915 \\
& & $X_{2}^{3}$ & 0.875 \\
& & $X_{3}$ & 0.183 \\
& & $X_{3}^{2}$ & 0.014 \\
& & $X_{3}^{3}$ & \\
\hline Model 4 & $76.2 \%$, & $X_{3}$ & 0.286 \\
& $69.7 \%$ & $X_{3}^{2}$ & 0.615 \\
& & $X_{3}^{3}$ & 0.967 \\
\hline Model 5 & $99.1 \%$, & $X_{2}$ & 0.000 \\
& $98.8 \%$ & $X_{3}$ & 0.046 \\
& & $X_{3}^{2}$ & 0.001 \\
& & $X_{3}^{3}$ & 0.000 \\
\hline
\end{tabular}

Suatu model regresi dikatakan sudah mewakili data apabila $\mathrm{p}$-value model regresi dalam Anova tidak melebihi level toleransi $(\alpha)$ yang telah ditetapkan. Selain menggunakan $p$-value, nilai statistik uji- $F$ dapat pula digunakan untuk menyimpulkan suatu model yang dibuat telah memenuhi kecukupan model.

Untuk menguji apakah koefisienkoefisian regresi tersebut signifikan atau tidak, dapat dilihat dari hasil perbandingan nilai antara $p$-value/nilai sig.T dan nilai $\alpha$ $=5 \%$. Dengan kriteria jika $\alpha=5 \%>$ nilai sig.T maka koefisien regresi tidak signifikan, 
dan jika $\alpha=5 \%<$ nilai sig.T maka koefisien regresi signifikan. model

Dari Tabel 1 dapat dilihat bahwa

$Y=a_{5}+b_{51} X_{2}+b_{52} X_{3}+b_{53} X_{3}^{2}+b_{54} X_{3}^{3}$ yang terbaik, karena nilai $R^{2}=99,1 \%$ dan nilai $R$-Sq(adj) $=98,8 \%$ serta seluruh koefisien regresinya signifikan.

\section{KESIMPULAN}

Berdasarkan pengujian yang telah dilakukan, maka dapat disimpulkan bahwa :

1. Model terbaik dari kelima model yang telah diuji adalah persamaan regresi model $Y=a_{5}+b_{51} X_{2}+b_{52} X_{3}+b_{53} X_{3}^{2}+b_{54} X_{3}^{3}$ dimana keseluruhan koefisiennya signifikan. Hal ini dapat dilihat dari nilai koefisien determinasi sebesar $99,1 \%$ dan nilai $R$-Sq(adj) sebesar 98,8\%.

2. Untuk mencari model terbaik tidak hanya dilihat dari nilai koefisien determinasinya saja, hal ini bisa dilihat dari hasil persamaan model 3 yaitu $Y=b_{03}+b_{13} X_{2}+b_{23} X_{2}^{2}+b_{33} X_{2}^{3}+b_{43} X_{3}+b_{53} X_{3}^{2}+b_{63} X_{3}^{3}$ dimana $\mathrm{R}^{2}$ sebesar $99,2 \%$ nilai ini lebih tinggi dibanding dengan nilai koefisien determinasi dari model lainnya, tapi setelah dilakukan uji terhadap koefisienkoefisien secara parsial ternyata tidak semua nilai yang signifikan.

3. Derajat tertinggi yang didapat yaitu derajat kubik (polinomial pangkat tiga).

\section{DAFTAR PUSTAKA}

Boediono, W. Koster. 2001. Statistika dan Probabiltas. Edisi ke-1. Rosda, Bandung.

Iriawan, N.S., P. Astuti. 2006. Mengolah Data Statistik dengan Mudah Menggunakan Minitab 14. Andi, Yogyakarta.

Neter, J., W. Wasserman dan M. H. Kutner. Applied Linear Statistical Models, ed.2. Homewood.

Sembiring, R.K. 1995. Analisis Regresi. ITB, Bandung.

Setiawan. D., E. Kusrini. 2010. Ekonometrika. Andi, Yogyakarta.

Simamora, H. 2002. Akuntansi Manajemen. Salemba Empat. Jakarta.

Sudayat, R. I. 2009. Pengertian Penjualan. http://ridwaniskandar.files.wordpress. com/2009/05/32-penggolonganbiaya.pdf. [9 Oktober 2012].

Supriyono. 2000. Akuntansi Biaya. Edisi ke-2. BPFE.Yogyakarta. 